NASA/TM-2009-215447

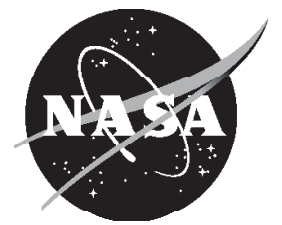

\title{
An Overview of NASA's Contributions to Energy Technology
}

Valerie J. Lyons

Glenn Research Center, Cleveland, Ohio

Arlene S. Levine

Langley Research Center, Hampton, Virginia 


\section{NASA STI Program . . . in Profile}

Since its founding, NASA has been dedicated to the advancement of aeronautics and space science. The NASA Scientific and Technical Information (STI) program plays a key part in helping NASA maintain this important role.

The NASA STI Program operates under the auspices of the Agency Chief Information Officer. It collects, organizes, provides for archiving, and disseminates NASA's STI. The NASA STI program provides access to the NASA Aeronautics and Space Database and its public interface, the NASA Technical Reports Server, thus providing one of the largest collections of aeronautical and space science STI in the world. Results are published in both non-NASA channels and by NASA in the NASA STI Report Series, which includes the following report types:

- TECHNICAL PUBLICATION. Reports of completed research or a major significant phase of research that present the results of NASA programs and include extensive data or theoretical analysis. Includes compilations of significant scientific and technical data and information deemed to be of continuing reference value. NASA counterpart of peer-reviewed formal professional papers but has less stringent limitations on manuscript length and extent of graphic presentations.

- TECHNICAL MEMORANDUM. Scientific and technical findings that are preliminary or of specialized interest, e.g., quick release reports, working papers, and bibliographies that contain minimal annotation. Does not contain extensive analysis.

- CONTRACTOR REPORT. Scientific and technical findings by NASA-sponsored contractors and grantees.

- CONFERENCE PUBLICATION. Collected papers from scientific and technical conferences, symposia, seminars, or other meetings sponsored or cosponsored by NASA.

- SPECIAL PUBLICATION. Scientific, technical, or historical information from NASA programs, projects, and missions, often concerned with subjects having substantial public interest.

- TECHNICAL TRANSLATION. Englishlanguage translations of foreign scientific and technical material pertinent to NASA's mission.

Specialized services also include creating custom thesauri, building customized databases, organizing and publishing research results.

For more information about the NASA STI program, see the following:

- Access the NASA STI program home page at http://www.sti.nasa.gov

- E-mail your question via the Internet to help@ sti.nasa.gov

- Fax your question to the NASA STI Help Desk at 301-621-0134

- Telephone the NASA STI Help Desk at 301-621-0390

- Write to: NASA Center for AeroSpace Information (CASI) 7115 Standard Drive Hanover, MD 21076-1320 
NASA/TM—2009-215447

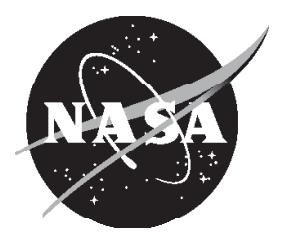

\section{An Overview of NASA's Contributions to Energy Technology}

Valerie J. Lyons

Glenn Research Center, Cleveland, Ohio

Arlene S. Levine

Langley Research Center, Hampton, Virginia

Prepared for the

Sixth International Energy Conversion Engineering Conference and Exhibit (IECEC)

sponsored by the American Institute of Aeronautics and Astronautics

Cleveland, Ohio, July 28-30, 2008

National Aeronautics and

Space Administration

Glenn Research Center

Cleveland, Ohio 44135 


\section{Acknowledgments}

The authors would like to thank the National Aeronautics and Space Administration for funding these efforts over the decades. We are also indebted to Virginia Dawson for her efforts to capture many of NASA Lewis' energy efforts of the past (Dawson, Virginia P., "Engines and Innovation,” NASA SP-4306, 1991, pp. 201-215).

Trade names and trademarks are used in this report for identification only. Their usage does not constitute an official endorsement, either expressed or implied, by the National Aeronautics and Space Administration.

Level of Review: This material has been technically reviewed by technical management.

Available from

NASA Center for Aerospace Information 7115 Standard Drive

Hanover, MD 21076-1320
National Technical Information Service 5285 Port Royal Road Springfield, VA 22161 


\title{
An Overview of NASA's Contributions to Energy Technology
}

\author{
Valerie J. Lyons \\ National Aeronautics and Space Administration \\ Glenn Research Center \\ Cleveland, Ohio 44135 \\ Arlene S. Levine \\ National Aeronautics and Space Administration \\ Langley Research Center \\ Hampton, Virginia 23681
}

\begin{abstract}
The National Aeronautics and Space Administration (NASA) is well known for its many contributions to advancing technology for the aviation and space industries. It may be surprising to some that it has also made a major impact in advancing energy technologies. This paper presents a historic overview of some of the energy programs that NASA was involved in, as well as presenting some current energy-related work that is relevant to both aerospace and nonaerospace needs. In the past, NASA developed prototype electric cars, low-emission gas turbines, wind turbines, and solar-powered villages, to name a few of the major energy projects. The fundamental expertise in fluid mechanics, heat transfer, thermodynamics, mechanical and electrical engineering, and other related fields, found in NASA's workforce, can easily be applied to develop creative solutions to energy problems in space, aviation, or terrestrial systems.
\end{abstract}

\section{Introduction}

This paper provides an overview of some of NASA's major contributions to energy systems which has many facets. Since NASA has had to develop many self-sustaining power systems for space missions, such as the International Space Station, Mars and Lunar Rovers, crewed spacecraft, many satellites and deep space probes, as well as aeronautical applications, expertise gained from these aerospace power systems has been useful for applications to terrestrial systems in the past and has potential for solving energy needs in the future. This paper presents a description of the history of some past energyrelated NASA projects and how it has laid groundwork for application to today's energy needs - both aerospace and terrestrial.

\section{Background and History}

The 1970s brought an energy crisis in the form of an oil embargo and rising fuel costs and the awareness of anthropogenic-caused global climate change. The former led to NASA research programs in alternative energy and energy conservation. The later led to investigations on the impact of human activities on the composition and chemistry of the atmosphere and on climate. The NASA Authorization Act in 1974 permitted NASA to undertake energy-related efforts. The Committee on Aeronautical and Space Sciences stated that, "NASA has broad capabilities that can and should be studied fully for their potential application to solving the energy shortage facing the Nation." No specific project was stated; rather NASA was expected to identify studies that would identify research and hardware demonstrations. Two million dollars were authorized for this research. NASA was charged to continue to cooperate with the National Science Foundation's energy programs. NASA's Langley and Lewis (now Glenn) Research Centers began an extensive effort on this newly authorized energy program, which is the subject of this paper. Marshall Spaceflight Center in Huntsville, Alabama, also carried on energy research during this period, but this is beyond the scope of this paper. Green technology research performed at the NASA Langley Research Center included a wide-range of activities focusing on atmospheric science which assessed the impact of human activities, including the impact of fossil fuel combustion on the atmosphere's composition, chemistry and climate to aeronautics programs with goals to develop "green" airplanes.

\section{Environmental Crisis and Response}

In northern Ohio, air and water pollution due to Cleveland's steel mills led to a 1969 oil slick on the Cuyahoga River that caught fire and got national attention. In the 1970s, concern for the environment became more intense, especially as new satellites and advancements in space science sent back data showing how rare and fragile life was in the solar systemand how our thin layer of atmosphere was all that protected us from the harshness of space. Meanwhile, at NASA, postApollo staff cuts led to searches for new work areas in order to avoid losing more engineers and scientists. In order to reeducate the workforce, NASA Lewis developed an in-house series of graduate courses on environmental problems: pollution from cars, planes, nuclear and electric power generation. However, at this time, research was seen as expendable as NASA's focus at this time was on the development of the new Space Shuttle and other space and aeronautics hardware products. 


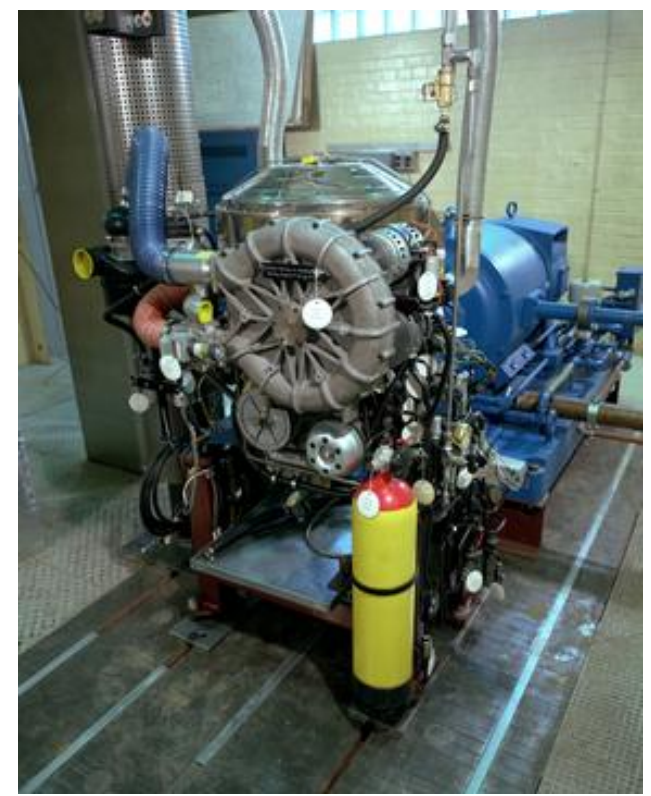

Figure 1.-Early 1970s Automotive Stirling Test Cell at NASA Lewis.

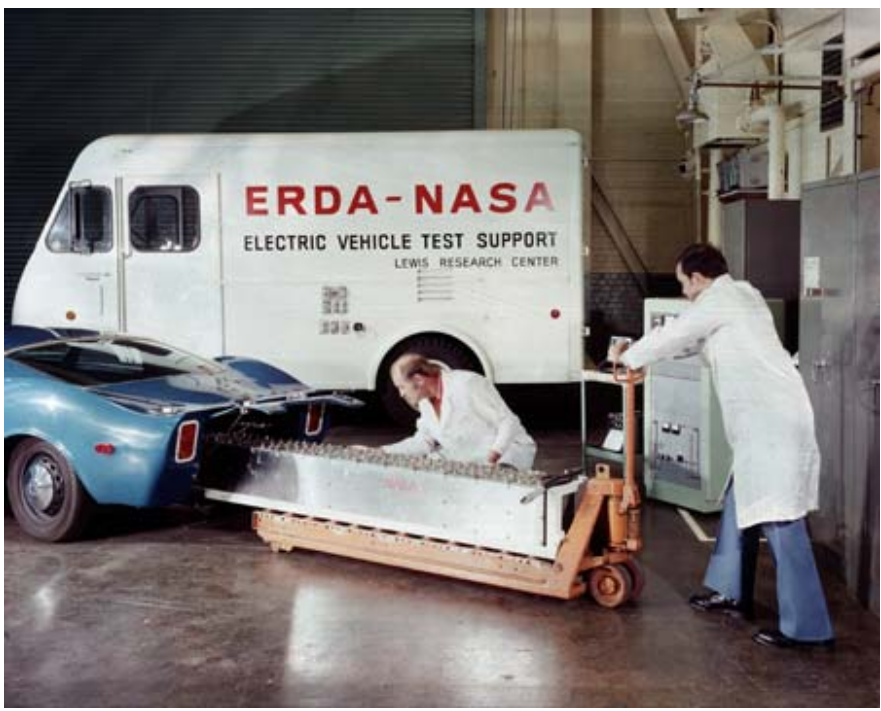

Figure 2.-Lead-Acid Battery-Powered Car at NASA Lewis.

In 1970, NASA Lewis engineer, Robert Graham sent a memo to Center Director Bruce Lundin suggesting that Lewis undertake energy research, due to its capabilities in thermodynamics, fluid mechanics, heat transfer, materials, chemistry, nuclear physics, plasma physics and cryo-physics all in one organization. This led to the establishment of the Automotive Systems Office funded by the EPA to develop gas-turbines as cleaner-burning automobile engines. Later Stirling engine technology and electric (battery-powered) cars were developed and demonstrated.

In 1971 the Environmental Research Office at Lewis was established which monitored pollutants in the atmosphere. An EPA-funded program studied wastes affecting Lake Erie, where an aircraft was used to monitor algae, crop diseases, strip mining, and ice on Lake Erie. In 1972, a solar-powered remote control station on Lake Erie was set up along with eight other stations around Cleveland to study the effect of weather on pollution.

The 1973 Energy crisis was seen as a solution for NASA's staffing crisis; Bob English, Chief of Space Power System Division, saw energy conversion as the heart of Lewis' expertise. Brayton-cycle technology was seen as an answer to cleaner, more energy efficient transportation systems. The Department of Transportation and the EPA funded Lewis to do research on a Rankine system, used in space power, to improve coal-fired electric power plants. Nixon set up task force on energy, with 15 panels-NASA Lewis had representatives on the Energy Conversion, Solar Energy (including wind), Fusion Energy, and Advanced Transportation Systems Panels.

A series of major NASA programs ensued, where engineers at Lewis and Langley Research Centers, among others, began investigating the atmosphere, air and water quality, emissions reduction, and climatic impact assessments. A summary of some of these efforts follows:

- $\quad \mathrm{SO}_{2}$ and $\mathrm{NO}$ pollutant emissions from smoke stacks (power station in North Carolina) were successfully measured by remote sensing in 1972. Measurements were made with LASER radar modified to detect "Raman" light emissions by the gases of interest. The EPA assigned this task with the objective of Langley designing a prototype instrument tailored to meet EPA needs.

- Global Air Sampling Program (GASP) started in the mid to late 1970s: Lewis engineers, in partnership with industry, instrumented and gathered data from aircraft worldwide, including commercial flights, to determine the level of pollutants in the atmosphere.

- $\quad$ Stratospheric Cruise Emission Reduction Program (SCERP), began in the late 1970s. At NASA Lewis, engineers generated a great deal of combustion data to guide aircraft engine companies in the design of gas turbine combustors that would release fewer emissions of $\mathrm{NO}_{\mathrm{x}}$ and $\mathrm{CO}$ in the Stratosphere. This addressed atmospheric ozone depletion and the "green-house" effect which would result from a large number of jet aircraft flying at this altitude, where the weather does not assist in depleting these pollutants over time.

- Limb Infrared Monitor of the Stratosphere (LIMS), launched in 1978: Langley obtained the first global measurements of water vapor and key nitrogen species that impact stratospheric ozone; identified relative role of transport vs. chemistry in ozone chemistry. 
- Stratospheric Aerosol Measurement II (SAM II), launched in 1978: NASA Langley discovered "polar stratospheric clouds," which were found to have a significant role in ozone depletion in the Antarctic stratosphere.

- Stratospheric Aerosol and Gas Experiment (SAGE I, II, and III) launched in 1979, 1985, and 2001: Langley scientists defined a trend in stratospheric ozone distribution and concentration over a period of two decades. Defined global impacts of volcanic eruption (Mt. Pinatubo) on Earth's climate (SAGE II). Provided a better understanding of how natural processes and human activities may influence our climate (SAGE III).

- Simulation of full interactions of energy transfer, chemical, and dynamical processes that determine ozone distribution; simulation of ozone hole formation; assessment of impact of aircraft on ozone layer (global atmospheric modeling), NASA Langley and Lewis - 1989 to 1996.

- The Halogen Occultation Experiment (HALOE), launched 1991: Langley researchers defined trends in the stratospheric chlorine budget. Verified impact of anthropogenic emissions on global atmospheric chemistry and effectiveness of Montreal Protocol.

- Earth's Radiation Budget Experiment (ERBE), launched in 1985: Langley obtained the first definitive global measurements of the effects of clouds on the Earth's planetary energy balance.

- Atmospheric Science Data Center (ASDC) at NASA Langley was established in 1991: Responsible for the processing, archival, and distribution of NASA Earth science data in the areas of radiation budget, clouds, aerosols, and tropospheric chemistry. The Data Center was to support the Earth Observing System (EOS) as part of NASA's Earth Science enterprise and the U.S. Global Change Research Program, and is one of several Distributed Active Archive Centers (DAACs) sponsored by NASA as part of the Earth Observing System Data and Information System (EOSDIS). The Data Center specializes in atmospheric data important to understanding the causes and processes of global climate change and the consequences of human activities on the climate. ASDC customers include scientists; researchers; federal, state, and local governments; educational and commercial professionals; application users; the commercial remote sensing community; and the general public.

- Contrail Research, started in 1994 at NASA Langley: Determined the impact of contrails on the
Earth's climate, part of the NASA subsonic aircraft assessment project, part of Atmospheric Effects of Aviation (AEAP) Program. The researchers use satellite, aircraft, and surface observations to determine the frequency of occurrence, microphysical properties, and radiative effects of contrails. Contrails morph into cirrus clouds, which reduce radiative heat loss thus adding to the green house effect.

- Clouds and the Earth's Radiant Energy System (CERES), launched in 1999: Langley obtained precise details about the makeup of the incoming solar radiation and the actual temperature at the surface, collected on a global scale, this data is used so that Renewable Energy Technologies (RETs, such as solar energy, wind power, and biomass fuels such as corn-based ethanol) can obtain their fullest potential. The National Renewable Energy Laboratory has developed a decision support system (DSS) to help policy makers. Planners require very detailed climatic data.

- Cloud-Aerosol Lidar and Infrared Pathfinder Satellite Observations (CALIPSO), launched in 2003: Satellite program to investigate the impact of clouds and aerosols on the Earth's radiation budget and climate was led by NASA Langley.

- Langley's Biomass Burning Program, ran from 1985 to 1995: Goal of research: To quantify the gaseous and particulate emissions from burning biomass and vegetation in diverse ecosystems, Langley researchers, for the first time, quantified the gaseous and particulate emissions from burning vegetation in the diverse ecosystems of our planet, including: tropical rain forests (Mexico and South America), boreal forests (Canada and the former Soviet Union), temperate forests (east coast of United States), Chaparral ecosystems (California), wetlands (Florida) and savanna grasslands (South Africa). The Langley research team also visited Kuwait at the invitation of the U.S. Department of Defense and the Department of State and quantified the gaseous and particulate emissions emanating from the Kuwaiti oil fires, following the first Gulf War. The Biospherics Research Program at NASA Headquarters funded this research.

- $\quad \boldsymbol{G L O B E}$ studies of tropospheric ozone was performed by students worldwide.

- Infusing satellite data into environmental applications (IDEA) project: August 2003 to present. Focus: Improving National air quality forecasts with satellite aerosol observations; Infusing satellite data into environmental applications (IDEA) is a 
partnership among NASA Langley, EPA, and NOAA in an effort to improve air quality assessment, management, and prediction by infusing satellite measurements (from NASA) into analyses (by EPA and NOAA) for public benefit. IDEA is a part of the NASA Applied Sciences Program strategy to demonstrate practical uses of NASA-sponsored observations from space and predictions from scientific research. Satellite aerosol observationswhich are particularly helpful in tracking long-range transport aloft - can overcome some of the limitations of surface monitoring networks and enhance daily air quality forecasts associated with particle pollution. The project was featured on the cover of the September 2005 "Bulletin of the American Meteorological Society." The product is being transitioned to NOAA for use as in operational air quality forecast guidance.

- Realtime Air Quality Modeling System (RAQMS) Project: September 2006 to present. Rapid Synthesis of Measurements and Models to Assess Regional Influences on Local Air Quality. The RAQMS is a partnership between the University of Wisconsin, NASA, and NOAA designed to prototype the use of global satellite observations for air quality assessment and prediction. RAQMS is a chemical assimilation/ forecasting system that is used to provide a link between global and regional scale satellite observations, surface networks, and airborne measurements. During the 2006 Texas Air Quality Study II, the system was used to characterize the impact of emissions from remote sources on local Texas air quality. The results from this analysis were used to quantify the contributions of regional background ozone production on Houston and Dallas Air Quality within the TEXAQS II Rapid Science Synthesis Team (RSST).

\section{Renewable Energy Technology}

In 1970, the Secretary of the Interior of Puerto Rico requested the NASA Lewis Research Center to design a wind turbine to generate power on the Island of Culebra. This attracted the attention of the National Science Foundation (NSF) which decided to fund the demonstration of a prototype wind turbine based on this design at Plumbrook, in Sandusky, Ohio. This was the Mod-0, $100 \mathrm{~kW}$ Experimental Wind Turbine. The NASA Authorization Act, 1974, permitted NASA to undertake energy-related efforts. The Mod-0 Wind Turbine inspired the establishment in 1974 of a $\$ 1.5 \mathrm{M}$ Wind Energy Program at NASA Lewis, funded by NSF and the Energy Research and Development Administration (ERDA). Throughout the Program, a total of 13 experimental wind turbines were put into operation. This included four major designs: $200 \mathrm{~kW}, 2000 \mathrm{~kW}, 2.5 \mathrm{MW}$ and the world's largesta 3.2 MW wind turbine.

At NASA Langley, Dr. John Buckley and a team of engineers installed a $14 \mathrm{ft}$ vertical axis Darrieus windmill atop Building 1225 in February 1974. Its purpose was to test its potential to provide energy for a single-family dwelling.

NASA Lewis became so involved in energy research and development that in 1974, rumors circulated that Lewis would sever relations with NASA and become part of ERDA. But, in 1977, with the creation of the Department of Energy, the Federal government decreed that energy programs were to be managed from Washington, D.C. This limited NASA's involvement to a consulting role. NASA Headquarters cut back the number of employees working on energy programs drastically and placed a 350 full-time-equivalent (FTE) limit on Lewis involvement in energy programs. Due in a large part to this imposed mandate, in 1977 the Lewis Center Director Bruce Lundin resigned. Subsequent Lewis Center Directors brought the Center back into NASA-funded aeronautics and space projects; the energy experts began to put their efforts into space power and gas-turbine fuel efficiency and emissions reduction, among other tasks.

A major foundation of renewable energy is the use of photovoltaics, or solar cells to convert sunlight to electricity. In 1978, Lewis engineers used solar cell technology developed for space applications to build the world's first solar-powered village in Schuchuli, Arizona, for the Papago Tribe. From 1975 to 1985 , a team from NASA Lewis in Cleveland, Ohio, designed, fabricated, and installed 58 photovoltaic systems in 28 developing countries.

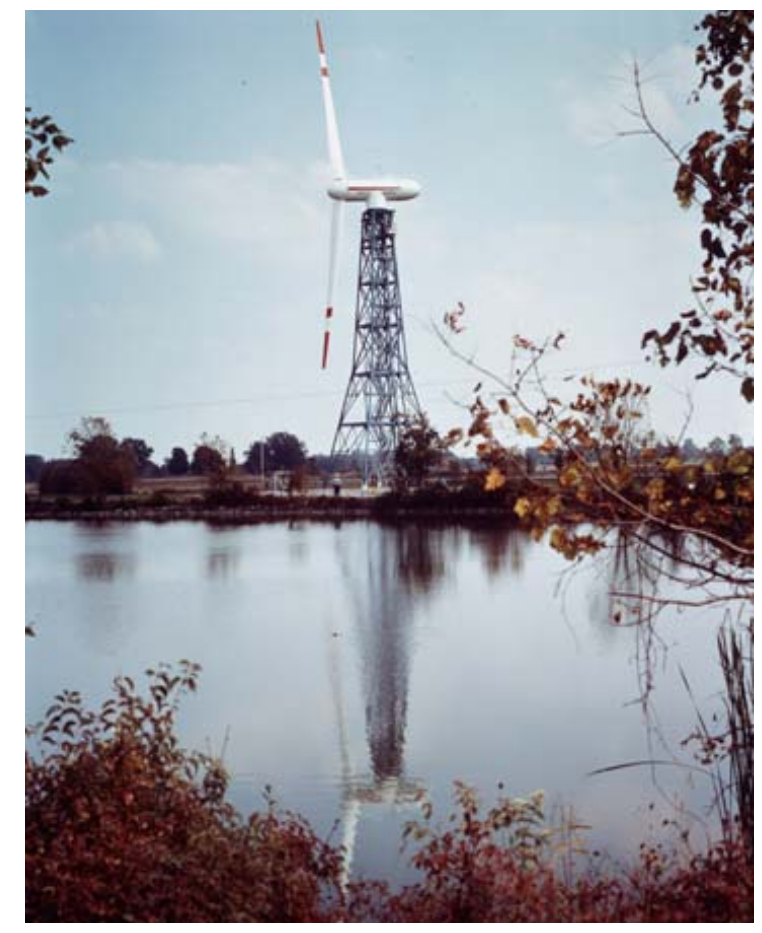

Figure 3.-NASA Lewis' Mod-0 Wind Turbine at Plumbrook. 


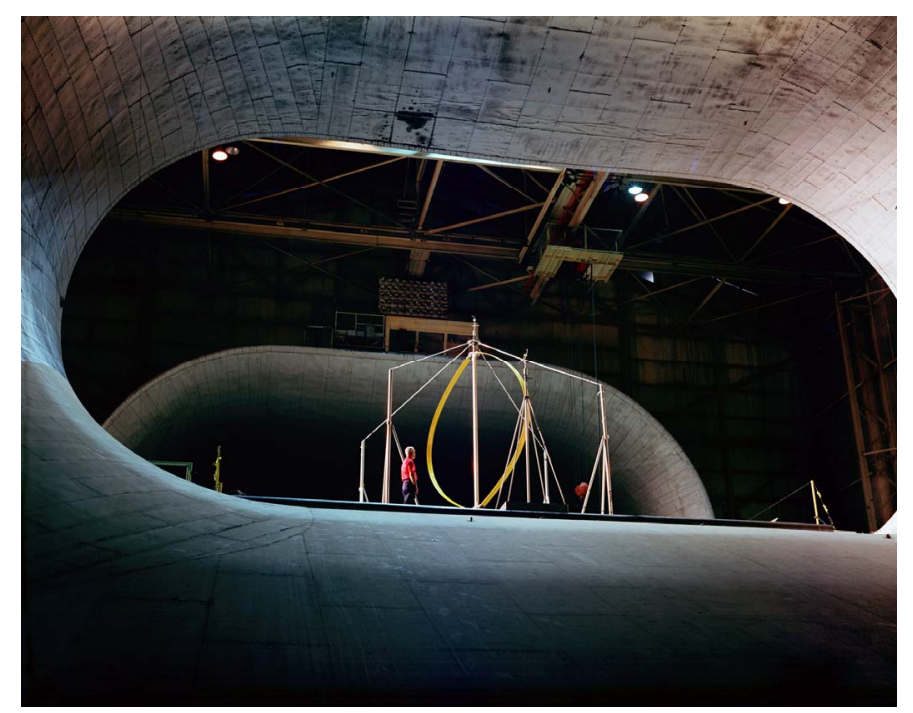

Figure 4.-Darrieus Windmill in a Langley Wind Tunnel Test.

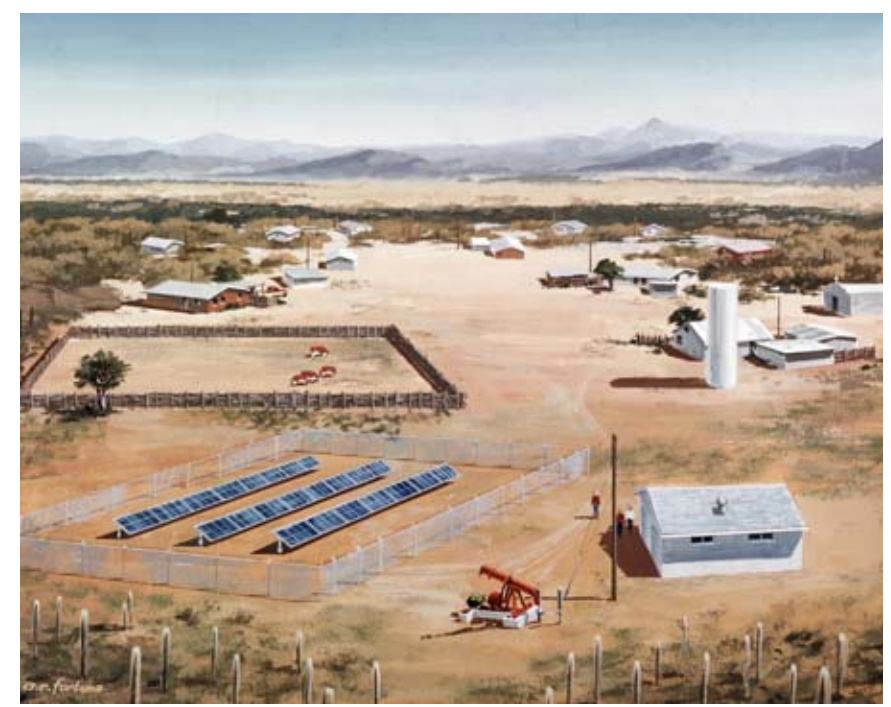

Figure 5.-NASA Lewis' sponsored the World's First SolarPowered Village.

Much of the advancement of solar cell technology came from the need for powering spacecraft. Back in 1957, Vanguard 1 was the first solar-powered satellite. The solar cells were only 5 percent efficient, but they enabled power to the satellite that lasted 7 years, as opposed to only 20 days of battery power! NASA Lewis (now Glenn) has a long history of world-class photovoltaic research and development, which has led to more efficient, more versatile, lighter, and more durable solar cells and solar arrays. The International Space Station is the largest solar-powered space vehicle ever built, using 14.5 percent efficient silicon cells. The new Orion, Crew Exploration Vehicle, which is now on the drawing board, will also be solar powered. Currently-available gallium arsenide multi-junction solar cells approach conversion efficiencies of
30 percent. Quantum dot technology, currently under development, theoretically could produce solar cells well over 50 percent efficient.

At Langley, a "Technology Utilization House" was completed in 1976 and a family lived in the house for one year from August 1977 to 1978. This technology demonstration was supported by the Technology Utilization Office showing how to apply new technologies, including aerospace technology, to the home building industry. It demonstrated solar systems, energy and water conservation, design concepts, safety, and security technology. Energy consumption was less than half the amount estimated for a reference home, although it was a colder than normal winter and had less than normal solar energy available in the fall. Water usage was 33 percent less than the reference house (ref. 1).

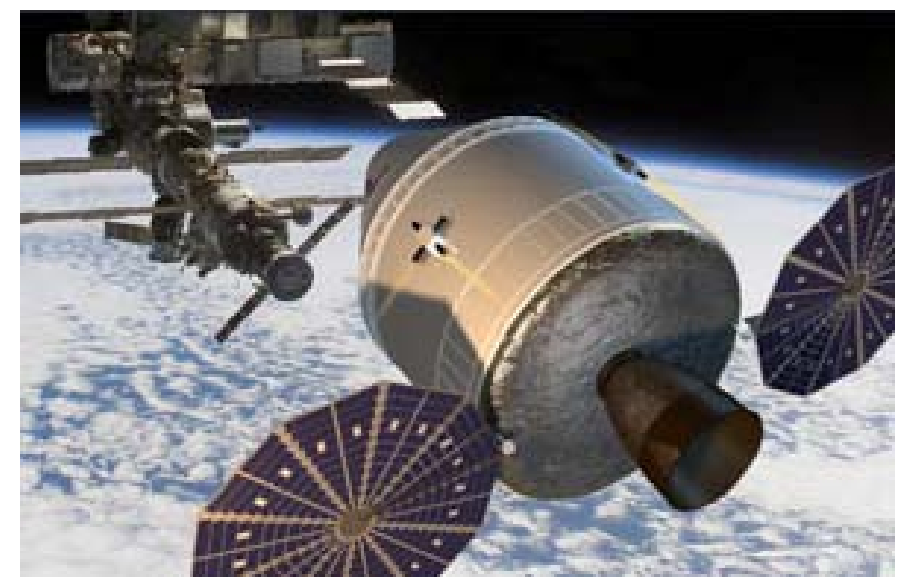

Figure 6.-Solar arrays power the Space Station and the proposed Orion Spacecraft.

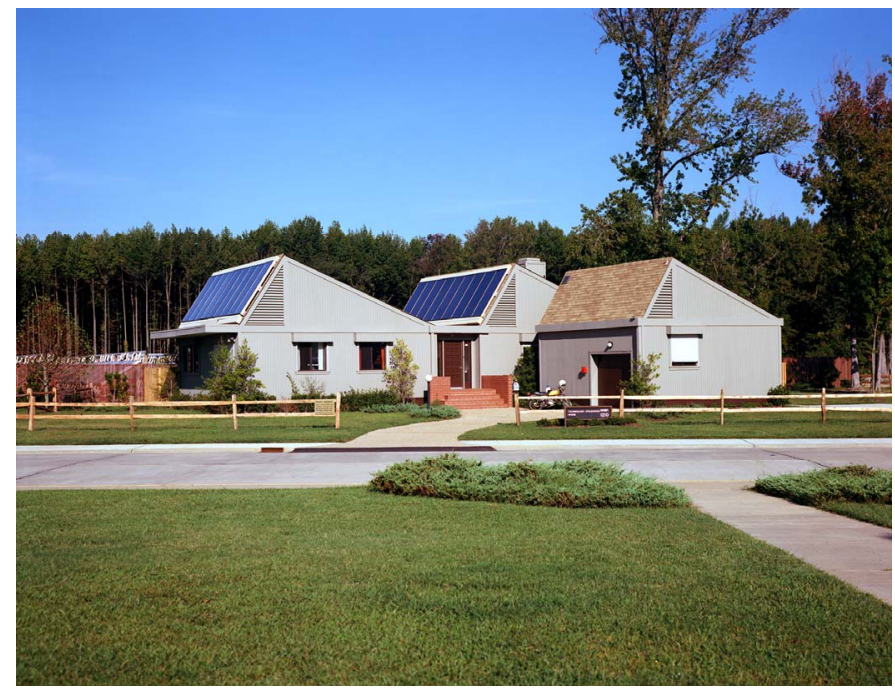

Figure 7.-NASA Langley's "Technology Utilization House" in 1976. 
In 1980, a new trash-burning steam plant solved a local environmental problem of disposing of refuse and providing fuel for energy production. Jointly sponsored by NASA Langley and Langley Air Force Base, the plant (still operating today) disposes of solid waste from the NASA center, the Air Force base, the Army's Fort Monroe and about 70 percent of the City of Hampton's municipal waste. The incinerator's refuse is reduced to disposable ash whose volume is one-seventh that of the solid waste. The energy produced in the burning process is converted to steam for use in research and administrative facilities at Langley Research Center. This both decreases the need for landfill, and decreases the cost of fuel oil needed to generate steam for Langley facilities.

From 1983 to 2006, the Surface Meteorology and Solar Energy (SSE) Project, managed by NASA Langley, worked with other government and private organizations to develop the commercial potential of NASA satellite measurements. The SSE Project put state-of-the-art, satellite-derived solar and meteorological data into the hands of individuals involved in the research and analysis of the feasibility of renewable energy technologies, sustainable buildings and agro-technology.

From a "green energy" consideration, heat may be thought of as wasted energy. Electrical power generated via waste heat from nuclear power plants, the exhaust system of automobiles, airplanes, or other vehicles, to the heat lost through the roof of our homes are very attractive applications. Using this heat to generate power helps the environment through greater combined electrical system efficiencies while concurrently lowering the incurred cost to operate these systems. A Stirling engine uses the potential energy difference between the hot end and cold end of its piston to establish a cycle of a fixed amount of gas expanding and contracting within the engine, thus converting a temperature difference across the machine into mechanical power. This mechanical power can be used to drive a vehicle, or to run a linear alternator to produce electricity (a Stirling convertor). A Stirling engine is a heat engine with no valves and is cleaner, quieter and more efficient than gasoline and diesel engines. In the 1970s, NASA Lewis' Stirling work focused on automotive engines that would eventually use hydrogen as the working fluid. NASA Glenn now has accumulated over 30 years of experience in research, analysis, testing and development of Stirling technology - in particular, the innovative "free-piston Stirling convertor", and is a recognized world leader in power conversion and supporting technologies in a wide range of power levels from 10's of watts to multi-kilowatts. Stirling technology is being incorporated into commercial products, such as combined heat and power units that are now available in Europe. A Stirling convertor under development at NASA Glenn, in partnership with industry and academia, is reaching its final stages of readiness for incorporating into a power system for a deep space mission which will save 75 percent of the nuclear fuel compared to previous state-of-the-art systems.

Waste heat can also be used to drive thermoelectric effects. Since 2003, Langley researchers have made significant progress in the advancement and performance of thermoelectric (TE) materials and material systems. Thermoelectrics pertain to an area of materials whereby heating, cooling, and/or electrical power generation is accomplished due to the intrinsic nature of some materials and material effects. An advanced thermoelectric material was conceived with a metallic nanoparticle and semiconductor compound material system that offers a very high performance value. To date, the separate low and high temperature TE material solutions have measured values that are respectively 71 and 128 percent better than state-of-the-art comparables. A Langley Invention Disclosure on this novel concept was filed on November 25, 2003.

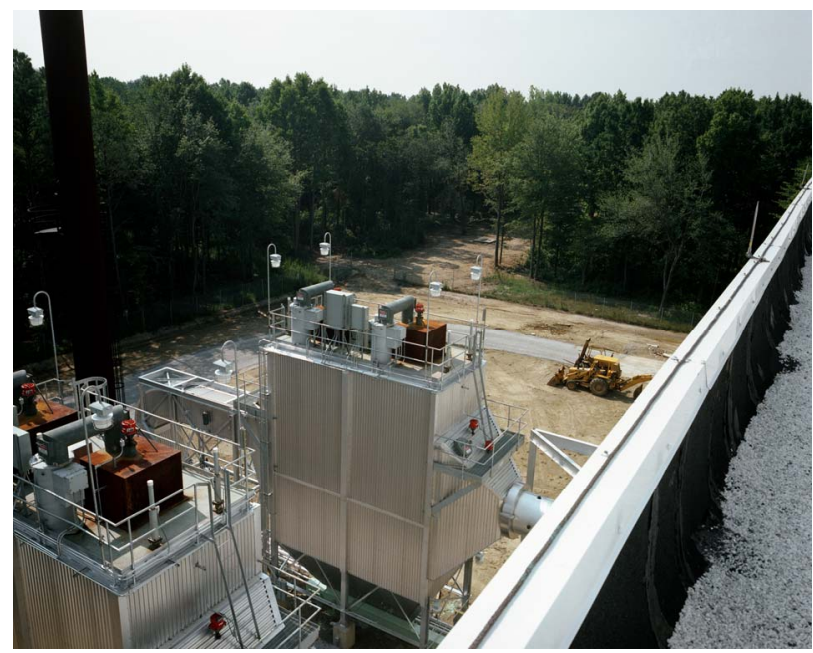

Figure 8.-NASA Langley's Trash-Burning Steam Plant was built in 1980 .

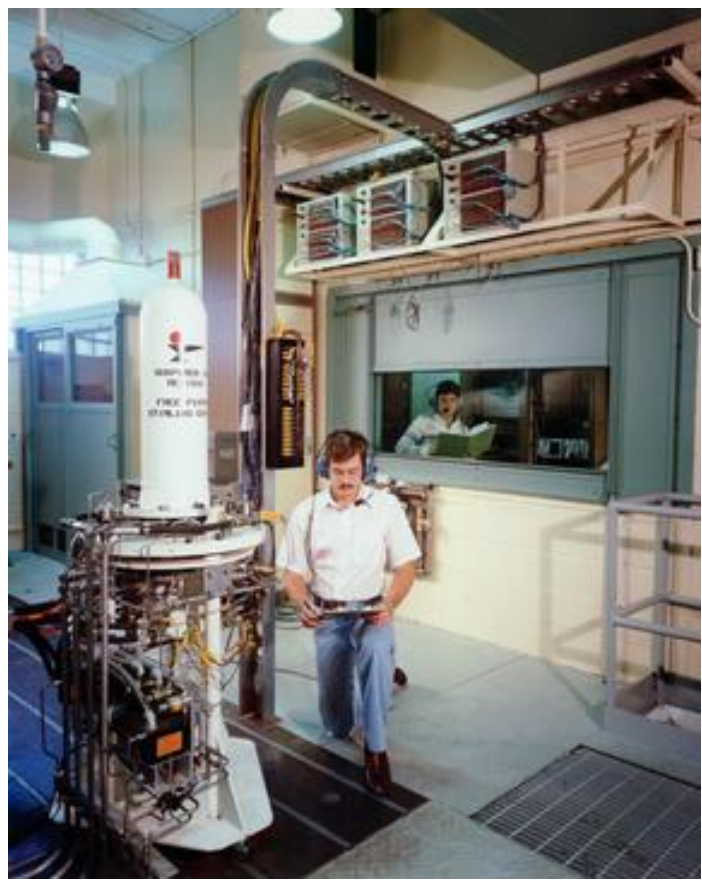

Figure 9.-NASA Lewis' Stirling research spans over 30 years. 
Another green energy concept involves generating hydrogen fuel using the large amount of waste heat generated from nuclear plants. This heat is ideal for keeping a solid oxide fuel cell at its proper operating temperature, enabling it to be used as an electrolyzer to generate hydrogen fuel. NASA Glenn is developing materials for use in solid oxide fuel cells and is working with Idaho National Labs, who have the nuclear expertise.

NASA has contributed greatly to the development of fuel cells, starting in the early Space Program where the use of a fuel cell to generate both electricity and water from hydrogen and oxygen was essential for use in a crewed spacecraft. Fuel cells are also being considered in a great many non-aerospace applications, including automotive and ground power, as a green power system alternative. From 2001 to 2003, a novel power system was developed to enable the Helios Solar Airplane to remain aloft during a high altitude flight for a 12-hr day and 12-hr night. This was a $600 \mathrm{~W}-\mathrm{hr} / \mathrm{kg}$ regenerative fuel cell system (RFC), which combined solar cells for day use and fuel cells for night. A more involved treatment of the history and impact of NASA's fuel cell involvement can be found in the paper by John H. Scott of Johnson Space Center entitled "NASA's Fuel Cell Contributions" (ref. 2).

\section{Aeronautics}

A look at NASA's investment and heritage in aeronautics may seem like an unlikely place for a discussion on renewable energy technology, but the research performed in the development of fuel efficient, low emission aircraft spins off valuable technology for the energy industry. Summaries of NASA's various past and current Aeronautics Program efforts and their contributions follow.

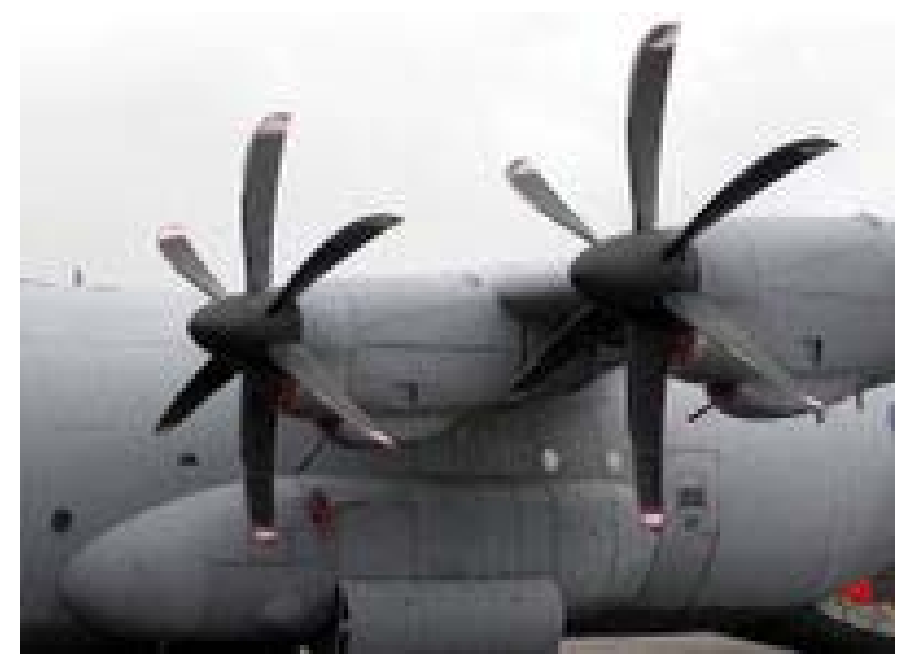

Figure 10.-NASA Lewis won a Collier Trophy for its FuelEfficient Advanced Turboprop.
Begun in 1976, the Aircraft Energy Efficiency (ACEE) Program was a national research and development effort to address the potentially disastrous impact of the fuel crisis of the early 1970 s on the air transportation system. The Energy Efficient Transport (EET) Program began in 1976 as an element of the NASA Aircraft Energy Efficiency Program. From 1973 to 1975 , the fuel prices paid by U.S. airlines almost tripled, and fuel costs rose from about 20 percent of a typical airline's direct operating costs in the early 1970s to 60 percent by 1982 . NASA's aeronautical research centers participated in the ACEE program, NASA Langley's areas of responsibility were: composites, laminar flow, advanced aerodynamics and active controls. Advanced aerodynamics research areas included high-aspect ratio supercritical wings, winglets, advanced high-lift systems, natural laminar flow, hybrid laminar flow control, nacelle aerodynamic and inertial loads, propulsion/airframe integration (e.g., long-duct nacelles), and wing and empennage surface coatings. Winglets reduce drag, increasing fuel efficiency as much as 3 to 7 percent. In the $1970 \mathrm{~s}$, Richard T. Whitcomb experimented with a little vertical wing, or winglet-extending above or below the wingtip hoping to mitigate the strength of the trailing vortex and reduce the wing's induced drag. Three thousand hours were spent testing in a Langley wind tunnel to optimize the winglet. "Perhaps no single NASA concept has seen such widespread use on an international level as Whitcomb's winglets," wrote NASA's Joseph R. Chambers.

Laminar flow research performed at Langley in the 1970s reduced turbulence over wings, nacelles, control surfaces and fuselages, to improve fuel-efficiency. Boeing Aircraft, Douglas Aircraft and Lockheed Aircraft performed composite materials research with technical oversight and coordination by Langley. The overall goal of the ACEE Composite Primary Aircraft Structures Program was to develop and conduct experiments that would lead to application of composites for small, secondary aircraft components in the 1980s and more complex larger scale structures in the 1990s providing weight reduction and a fuel savings of over 15 percent. The program helped to accelerate the application of composites to commercial transports by 5 to 10 years. However, it did not achieve its goal of developing composite primary wing and fuselage structures. A 1979 alternative aircraft fuel study at Langley compared liquid hydrogen, liquid methane, and synthetic aviation kerosene (coal-derived synjet). The viability of each fuel from a standpoint of cost, capital requirement, and energy resource utilization, as influenced by fuel production, transmission, airport storage and distribution facilities, and use in aircraft was examined. Environmental emissions and safety aspects of the various fuels were also considered and it was found that all three fuels were technically viable. Synjet was considered the most attractive fuel since at the time (1979) its production and transportation to the airport was the least expensive of the three alternative fuels (ref. 3).

During this time, NASA Lewis performed extensive research on improving the fuel efficiency of the aircraft propulsion system, developing the Collier-award-winning 
advanced turboprop concept. Lewis made many improvements to aircraft gas turbine engines, and researched alternative fuels. NASA Lewis contracted with GE, P\&W to do a turbine engine demonstration of a quiet, clean, Short Take-Off and Landing (STOL) Experimental Engine. By the time many of these successful NASA programs had ended, fuel costs were lower and the cost of implementing the results into actual aircraft was determined not to be cost effective. So, many of these aeronautics program products have yet to be put into service, but are still attractive possibilities.

Throughout NASA's history, including the present, a steady stream of aeronautics programs developing technology for improving aircraft while minimizing their environmental impact has been NASA's focus. In the past 10 years, NASA Glenn has worked on many propulsion-related projects. The "Zero $\mathrm{CO}_{2}$ Research" project sought to eliminate carbon dioxide $\left(\mathrm{CO}_{2}\right)$ and to lower nitrogen oxides $\left(\mathrm{NO}_{\mathrm{x}}\right)$ emissions from civil transportation aircraft by converting their propulsion systems to hydrogen fuel in order to reduce stress on the ozone layer. As part of this project, NASA Glenn engineers looked for ways to introduce new propulsion technologies - for instance, the use of fuel cells. In the "Smart Efficient Components" project, the principal aim was to seek out, develop and demonstrate technologies for subsonic aircraft that would minimize all environmentally harmful engine emissions. Since $\mathrm{NO}_{x}$ and $\mathrm{CO}_{2}$ environmental impacts must be considered (acid rain and greenhouse gases), the project sought to find ways to reduce the fuel burn of advanced aeropropulsion systems. In the "Revolutionary Aeropropulsion Concepts" the focus was on developing "NonTurbomachinery-Based Components and Systems" while seeking to enable emission-less propulsion. NASA Glenn continues to provide new technologies to provide more energy efficient fuels, materials, and concepts. The Ultra-Efficient Engine Technology (UEET) project focused on developing environmentally friendly, clean burning engines by developing technologies that enabled intelligent turbine engines to significantly reduce harmful emissions, but maintain high performance and reliability. The project included low emissions combustors, light-weight compressors and turbines, with a focus on subsonic, supersonic, and rotorcraft technologies. Optimizing propulsion-airframe integration minimized drag, thereby reducing $\mathrm{CO}_{2}$ emissions. Advanced high-temperature materials, such as ceramic matrix composites and disk alloys, and innovative lighter-weight materials, improved fuel efficiency.

Currently, at NASA Glenn there is an ongoing project in the Aeronautics Program focusing on Alternative Fuels Combustion research and development. The objective is to enable system-level trades of emissions and other performance factors for conventional and unconventional aircraft and develop emissions reduction and alternative fuels technologies that have minimal impact on aircraft operation while reducing U.S. dependence on foreign oil. The project involves modeling of combustion processes as well as experimental work on alternative fuels focusing on better understanding of the Fischer-Tropsch process for synthesizing fuels. Also, there is some interesting research currently underway at NASA Glenn to develop aviation fuels from biomass (ref. 4).

\section{Conclusion}

Although NASA is well-known for its Space Program and its many contributions to Aeronautics, it has also been a major contributor to energy systems and environmental technology. NASA is a valuable resource that can be tapped as we seek to address the compelling need to solve the current energy and environmental crises.

\section{References}

1. Abbott, I.H.A, Hopping, K.A, and Hypes, W.D, NASA Technical Paper 1564, "An Evaluation of the NASA Tech House Including Live-In Test Results, Volume 1," November 1979.

2. Scott, John H., "NASA's Fuel Cell Contributions," IECEC, AIAA-2008-5793, July 2008.

3. Witcofski, Robert D., "Comparison of Alternate Fuel for Aircraft,” NASA TM-80155, 1979.

4. Hendricks, Robert C., "Biomass Aviation Fueling Feedstocks," IECEC, AIAA-2008-5794 


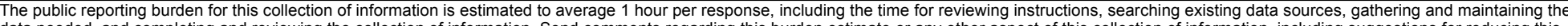

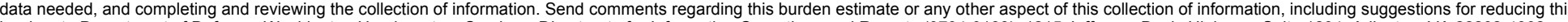

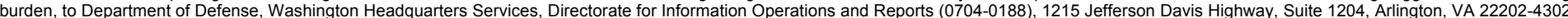

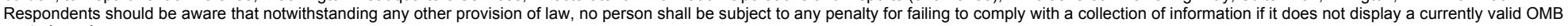
control number.

PLEASE DO NOT RETURN YOUR FORM TO THE ABOVE ADDRESS.

\section{REPORT DATE $(D D-M M-Y Y Y Y)$ \\ 2. REPORT TYPE \\ 3. DATES COVERED (From - To)}

01-01-2009

Technical Memorandum

\section{TITLE AND SUBTITLE}

An Overview of NASA's Contributions to Energy Technology

\section{5a. CONTRACT NUMBER}

5b. GRANT NUMBER

5c. PROGRAM ELEMENT NUMBER

6. AUTHOR(S)

Lyons, Valerie, J.; Levine, Arlene, S.

\section{5d. PROJECT NUMBER}

5e. TASK NUMBER

5f. WORK UNIT NUMBER

WBS 138494.04.01.01

8. PERFORMING ORGANIZATION REPORT NUMBER

E-16665

National Aeronautics and Space Administration

John H. Glenn Research Center at Lewis Field

Cleveland, Ohio 44135-3191

\section{SPONSORING/MONITORING AGENCY NAME(S) AND ADDRESS(ES)}

National Aeronautics and Space Administration

Washington, DC 20546-0001

10. SPONSORING/MONITORS
ACRONYM(S)
NASA
11. SPONSORING/MONITORING
REPORT NUMBER
NASA/TM-2009-215447

\section{DISTRIBUTION/AVAILABILITY STATEMENT}

Unclassified-Unlimited

Subject Category: 99

Available electronically at http://gltrs.grc.nasa.gov

This publication is available from the NASA Center for AeroSpace Information, 301-621-0390

\section{SUPPLEMENTARY NOTES}

\section{ABSTRACT}

The National Aeronautics and Space Administration (NASA) is well known for its many contributions to advancing technology for the aviation and space industries. It may be surprising to some that it has also made a major impact in advancing energy technologies. This paper presents a historic overview of some of the energy programs that NASA was involved in, as well as presenting some current energyrelated work that is relevant to both aerospace and nonaerospace needs. In the past, NASA developed prototype electric cars, low-emission gas turbines, wind turbines, and solar-powered villages, to name a few of the major energy projects. The fundamental expertise in fluid mechanics, heat transfer, thermodynamics, mechanical and electrical engineering, and other related fields, found in NASA's workforce, can easily be applied to develop creative solutions to energy problems in space, aviation, or terrestrial systems.

\section{SUBJECT TERMS}

Energy; History; Aeronautics; Emission reduction; Fuel efficiency; Wind power; Space power; Photovoltaics; Fuel cells; Climate; Atmospheric chemistry

\begin{tabular}{|c|c|c|c|c|c|}
\hline \multicolumn{3}{|c|}{ 16. SECURITY CLASSIFICATION OF: } & \multirow{2}{*}{$\begin{array}{l}\text { 17. LIMITATION OF } \\
\text { ABSTRACT } \\
\text { UU }\end{array}$} & \multirow{2}{*}{$\begin{array}{l}\text { 18. NUMBER } \\
\text { OF } \\
\text { PAGES } \\
14\end{array}$} & \multirow{2}{*}{$\begin{array}{l}\text { 19a. NAME OF RESPONSIBLE PERSON } \\
\text { STI Help Desk (email:help@sti.nasa.gov) } \\
\text { 19b. TELEPHONE NUMBER (include area code) } \\
\text { 301-621-0390 }\end{array}$} \\
\hline $\begin{array}{l}\text { a. REPORT } \\
\text { U }\end{array}$ & $\begin{array}{l}\text { b. ABSTRACT } \\
U\end{array}$ & $\begin{array}{l}\text { c. THIS } \\
\text { PAGE } \\
\text { U }\end{array}$ & & & \\
\hline
\end{tabular}



